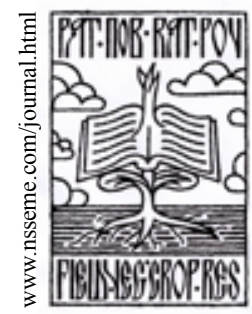

\title{
Okra (Abelmoschus esculentus (L.) Moench) as a Valuable Vegetable of the World
}

\section{Sorapong Benchasri}

\author{
received: 3 November 2011. received in revised form: 24 February 2012. accepted: 29 February 2012. \\ (c) 2012 IFVC \\ doi: $10.5937 /$ ratpov $49-1172$
}

\begin{abstract}
Summary: Okra is a commercial vegetable crop with considerable area under cultivation in Africa and Asia. Okra belongs to the family Malvaceae. It probably originated in Ethiopia and is widely spread all over tropical, subtropicalandwarmtemperateregionsoftheworld.Okraplaysanimportantrolein thehumandietbysupplying fats, proteins, carbohydrates, minerals and vitamins. Moreover, its mucilage is suitable for certain medical and industrial applications. Therefore, young fruits of okra have reawakened beneficial interest in bringing this crop into commercial production. The optimum yield of okra is approximately $6.6 \mathrm{tha}^{-1}$. Okra requires warm temperatures. The optimum temperatures are in the range of $20-30^{\circ} \mathrm{C}$, with minimum temperatures of $18^{\circ} \mathrm{C}$ and maximum of $35^{\circ} \mathrm{C}$. Okra needs rather high quantity of water despite having considerable drought resistance. The plant forms a deeply penetrating tap root with dense shallow feeder roots reaching out in all directions in the upper $45 \mathrm{~cm}$ of soil. Soil clamminess is essential during the continuation of growing period. Key words: Abelmoschus esculentus, breeding, composition, cultivation practice, diseases, insects, okra, origin, production
\end{abstract}

\section{Introduction}

Latin binomial names for okra are Abelmoschus esculentus and Hibiscus esculentus (Kumar et al. 2010), and it is commonly known as bhindi in India, krajiab kheaw in Thailand, okra plant, ochro, okoro, quimgombo, quingumbo, gombo, kopi arab, kacang bendi and bhindi in South East Asia. However, in Middle East it is known as bamia, bamya or bamieh and gumbo in Southern USA, and lady's finger in England (Ndunguru \& Rajabu 2004). On the other hand, in Portuguese and Angola, okra is known as quiabo, and as quimbombo in Cuba, gombo commun, gombo, gumbo in France, mbamia and mbinda in Sweden, and in Japan as okura (Chauhan 1972, Lamont 1999). Lastly, it is also found in Taiwan, where it is called qiu kui (Siemonsma \& Kouame 2000).

\section{Chemical composition}

Okra contains proteins, carbohydrates and vitamin C (Lamont 1999, Owolarafe \& Shotonde 2004, Gopalan et al.2007, Arapitsas 2008, Dilruba et al. 2009), and plays a vital role in human diet

\section{S. Benchasri}

Southern Tropical Plants Research Unit, Department of Agricultural Technology, Faculty of Technology and Community Development, Thaksin University, Phatthalung province P.O. Box 93110 Thailand e-mail: sorapong@tsu.ac.th
(Kahlon et al. 2007, Saifullah \& Rabbani 2009). Consumption of young immature okra pods is important as fresh fruits, and it can be consumed in different forms (Ndunguru \& Rajabu 2004). Fruits can be boiled, fried or cooked (Akintoye et al. 2011). The composition of okra pods per $100 \mathrm{~g}$ edible portion $(81 \%$ of the product as purchased, ends trimmed) is: water $88.6 \mathrm{~g}$, energy $144.00 \mathrm{~kJ}$ $(36 \mathrm{kcal})$, protein $2.10 \mathrm{~g}$, carbohydrate $8.20 \mathrm{~g}$, fat $0.20 \mathrm{~g}$, fibre $1.70 \mathrm{~g}, \mathrm{Ca} 84.00 \mathrm{mg}, \mathrm{P} 90.00 \mathrm{mg}$, Fe $1.20 \mathrm{mg}$, $\beta$-carotene $185.00 \mu \mathrm{g}$, riboflavin 0.08 $\mathrm{mg}$, thiamin $0.04 \mathrm{mg}$, niacin $0.60 \mathrm{mg}$, ascorbic acid $47.00 \mathrm{mg}$.

The composition of okra leaves per $100 \mathrm{~g}$ edible portion is: water $81.50 \mathrm{~g}$, energy $235.00 \mathrm{~kJ}$ ( 56.00 $\mathrm{kcal}$ ), protein $4.40 \mathrm{~g}$, fat $0.60 \mathrm{~g}$, carbohydrate $11.30 \mathrm{~g}$, fibre $2.10 \mathrm{~g}, \mathrm{Ca} 532.00 \mathrm{mg}, \mathrm{P} 70.00 \mathrm{mg}$, Fe $0.70 \mathrm{mg}$, ascorbic acid $59.00 \mathrm{mg}, \beta$-carotene $385.00 \mu \mathrm{g}$, thiamin $0.25 \mathrm{mg}$, riboflavin $2.80 \mathrm{mg}$, niacin $0.20 \mathrm{mg}$ (Gopalan et al. 2007, Varmudy 2011). Carbohydrates are mainly present in the form of mucilage (Liu et al. 2005, Kumar et al. 2009). That of young fruits consists of long chain molecules with a molecular weight of about 170,000 made up of sugar units and amino acids. The main components are galactose (25\%),

Acknowledgements: The author would like to express sincere gratitude to Southern Tropical Plants Research Unit, Faculty of Technology and Community Development and The Research and Development Institute Thaksin University, Thailand. 
rhamnose (22\%), galacturonic acid (27\%) and amino acids (11\%). The mucilage is highly soluble in water. Its solution in water has an intrinsic viscosity value of about $30 \%$.

Okra seeds contain about $20 \%$ protein and $20 \%$ oil (Tindall 1983, Charrier 1984). The bark fibre is easy to extract. It is white to yellow in colour, strong but rather coarse. Tests conducted in China suggest that an alcohol extract of okra leaves can eliminate oxygen free radicals, alleviate renal tubular-interstitial diseases, reduce proteinuria, and improve renal function (Liu et al. 2005, Kumar et al. 2009). In Thailand, okra is usually boiled in water resulting in slimy soups and sauces, which are relished. The fruits also serve as soup thickeners. Okra seed can be dried, and the dried seeds are a nutritious material that can be used to prepare vegetable curds, or roasted and ground to be used as coffee additive or substitute (Moekchantuk \& Kumar 2004). Okra leaves are considered good cattle feed, but this is seldom compatible with the primary use of the plant. The leaf buds and flowers are also edible (Doijode 2001).

Moreover, okra mucilage is suitable for industrial and medicinal applications (Akinyele \& Temikotan 2007). Industrially, okra mucilage is usually used for glace paper production and also has a confectionery use. Okra has found medical application as a plasma replacement or blood volume expander (Savello et al. 1980, Markose \& Peter 1990, Lengsfeld et al. 2004, Adetuyi et al. 2008, Kumar et al. 2010).

\section{World Marketing}

Okra production is estimated at 6 million $\mathrm{t}$ per year in the world (Burkil 1997). The total area of okra has increased over the years. In 1991-1992, the total area under okra cultivation was 0.22 million hectares and the production was 1.88 million $\mathrm{t}$, while in 2006-2007 the area increased to 0.396 million hectares and the production was 4.07 million t. Finally, in 2009-2010 the area was 0.43 million hectares and the production stood at 4.54 million t. Table 1 gives data on area, production and productivity of okra in the world (2008-2009), the share of India being 67.1\%, followed by Nigeria at $15.4 \%$ and Sudan at $9.3 \%$ (Varmudy 2011).

\section{Origin and Geographic Distribution}

Okra plant or lady's finger was previously included in the genus Hibiscus. Later, it was designated to Abelmoschus, which is distinguished from the genus Hibiscus (Aladele et al. 2008). Abelmoschus was subsequently proposed to be raised to the rank of distinct genus by Medikus in 1787. Okra originated somewhere around the Ethiopia, and was cultivated by the ancient Egyptians by the $12^{\text {th }}$ century BC. Its cultivation spread throughout Middle East and North Africa (Tindall 1983, Lamont 1999). Okra is grown in many parts of the world, especially in tropical and sub-tropical countries (Arapitsas 2007, Saifullah \& Rabbani 2009). This crop can be grown on a large commercial farm or as a garden crop (Rubatzky \& Yamaguchi 1997). Okra plants are grown commercially in many countries such as India, Japan, Turkey, Iran, Western Africa, Yugoslavia, Bangladesh, Afghanistan, Pakistan, Myanmar, Malaysia, Thailand, India, Brazil, Ethiopia, Cyprus and in the Southern United States (Purseglove 1987, Benjawan et al. 2007, Qhureshi 2007). Okra is found all around the

Table 1. Area production and productivity of okra in the world in 2008-2009

\begin{tabular}{lccc}
\hline Countries & & & \\
\hline India & Area (ha) & Production $(\mathrm{M} \mathrm{t})$ & ${\text { Productivity }\left(\mathrm{M} \mathrm{t} \mathrm{ha}^{-1}\right)}^{10.50}$ \\
Nigeria & 432,000 & $4,528,000$ & 2.70 \\
Sudan & 387,000 & $1,039,000$ & 10.20 \\
Iraq & 21,926 & 223,650 & 6.30 \\
Ivory Coast & 22,250 & 141,000 & 2.50 \\
Pakistan & 46,000 & 115,867 & 7.60 \\
Ghana & 15,081 & 114,657 & 5.50 \\
Egypt & 19,500 & 108,000 & 15.70 \\
Benin & 6,800 & 107,000 & 3.50 \\
Saudi Arabia & 13,658 & 48,060 & 11.50 \\
Others & 4,000 & 46,000 & 4.50 \\
Total & 58,365 & 276,206 & 6.60 \\
\hline
\end{tabular}

Source: Varmudy (2011) 
world from equatorial areas to Mediterranean Sea as may be seen from the geographical distribution of cultivated and wild species. Cultivated and wild species of okra clearly showed overlapping in Southeast Asia, which is considered as the centre of diversity. The spread of the other species is the result of their introduction to Africa and America (Qhureshi 2007, Aladele et al. 2008).

There are two hypotheses concerning the geographical origin of $A$. esculentus. Some scientists argue that one putative ancestor $(A$. tuberculatus) is native from Northern India, suggesting that the species originated from this geographic area. On the basis of ancient cultivation in East Africa and the presence of the other putative ancestor (A. ficulneus), others suggest that the area of domestication is Ethiopia or North Egypt, but no definitive proof is available today (Department of Biotechnology 2009). Abelmoschus species occur in the world including as A. moschatus, A. manihot, A. esculentus, $A$. tuberculatus, A. ficulneus, $A$. crinitus and $A$. angulosus (Charrier 1984). The three cultivated species which are sometimes found in a semi-wild state in clearings, along roads and near villages, occur at low altitudes in all tropical, subtropical and warm temperate regions of the world.
The species $A$. moschatus has a wide geographical distribution in India, Southern China, Indonesia, Papua New Guinea, Australia, Central and West Africa. The species $A$. manihot subsp. manihot is cultivated mainly in the East Asia, but also in the Indian sub-continent and Northern Australia. It is less frequently found in America and tropical Africa (Chevalier 1940). The species $A$. manihot subsp. tetraphyllus comprises two wild forms differentiated on the basis of their ecological adaptation. First, var. tetraphyllus, grows at low altitudes between 0 and $400 \mathrm{~m}$ in the regions with a marked dry season of Indonesia, Philippines, Papua New Guinea and New Ireland. Second, var. punens, grows at altitudes between 400 and 1600 $\mathrm{m}$ in Philippine and Indonesia (Department of Biotechnology 2009). The species A. esculentus is cultivated as a vegetable in most tropical and subtropical regions of Africa such as Ghana, Guinea, Ivory Coast, Liberia and Nigeria.

The wild species $A$. tuberculatus, related to $A$. esculentus, is endemic to the medium altitude hilly areas in India (IBPGR 1991). The wild species $A$. ficulneus is found in a vast geographic area stretching from Africa to Asia and Australia. It flourishes in tropical areas of low altitude with a long dry season, i.e. desert regions of Sahelian

Table 2. Chromosome numbers in Abelmoschus spp.

\begin{tabular}{|c|c|c|}
\hline Species & $\begin{array}{l}\text { Chromosome } \\
\text { numbers }(2 n)\end{array}$ & References \\
\hline A. esculentus & 66 & Ford (1938) \\
\hline A. esculentus & 72 & Ugale et al (1976), Datta \& Naug (1968), kamalova (1977) and Qhureshi (2007) \\
\hline A. esculentus & 120 & Purewal \& Randhawa (1947) and Datta \& Naug (1968) \\
\hline A. esculentus & 122 & Tischler (1931) \\
\hline A. esculentus & 124 & Kuwada $(1964,1966)$ \\
\hline A. esculentus & $126-134$ & Chizaki (1934) \\
\hline A. esculentus & 130 & Joshi \& Hardas (1976), Singh \& Bhatnagar (1975) and Kumar et al. (2010) \\
\hline A. manihot ssp. Manihot & 60 & Chizaki (1934) \\
\hline A. manihot ssp. Manihot & 66 & Kamalova (1977) \\
\hline A. manihot ssp. Manibot & 68 & Kuwada (1974) \\
\hline A. manihot ssp. tetraphyllus & 130 & Ugale et al. (1976) \\
\hline A. manihot Var. tetraphyllus & 138 & Joshi \& Hardas (1976) \\
\hline A. manihot ssp. tetraphyllus & 138 & Joshi \& Hardas (1976) \\
\hline A. moschatus & 72 & Gadwal et al. (1968) \\
\hline A. ficulneus & 72 & Kuwada $(1966,1974)$ and Gadwal et al. (1968) \\
\hline A. angulosus & 56 & Ford (1938) \\
\hline A. tuberculatus & 58 & Joshi \& Hardas (1953) \\
\hline
\end{tabular}

Source : Department of biotechnology (2009) 
Africa (Niger), Madagascar, East Africa, India, Indonesia, Malaysia and Northern Australia (Lamont 1999).The two wild species A. crinitus and $A$. angulosus are exclusively of Asian origin. They are differentiated by their ecology. A. crinitus grows at low altitudes in regions with a marked dry season, being (China, India, Pakistan and Philippines). $A$. angulosus grows at altitudes between 750 and $2000 \mathrm{~m}$ in Pakistan, India, Sri Lanka and Indonesia (Charrier 1984, IBPGR 1991).

\section{Cytogenetic Relationship}

There is a significant variation in the chromosome numbers and ploidy levels in Abelmoschus (Tab. 2). The highest chromosome number reported are close to 200 for $A$. manihot var. caillei, whereas the lowest chromosome numbers reported is $2 \mathrm{n}=56$ for $A$. angulosus (Ford 1938, Siemonsma 1982). The most frequently observed somatic chromosome number of okra is $2 n=130$. Although, Datta \& Naug (1968) suggest that the numbers chromosome $2 n=72$, $108,120,132$ and 144 are in regular series of polyploids with $n=12$. The existing taxonomical classifications at the species level in the genus Abelmoschus are unsatisfactory. Detailed cytogenetical observations on Asian material of okra and related species are likely to provide more examples of the existence of amphidiploids in the genus (Siemonsma 1982).

\section{Ecology and Season Growth}

Okra needs temperatures above $20^{\circ} \mathrm{C}$ for normal growth and development (Lamont 1999, Abd El-Kader et al. 2010). Germination percentage and speed of emergence are optimal at $30-35^{\circ} \mathrm{C}$ (Akande et al. 2003). Flower initiation and flowering are delayed with increasing temperatures (positive correlation between temperature and number of vegetative nodes) (Lamont 1999, Abd El-Kader et al. 2010). Abelmoschus spp. is a shortday plant, but its wide geographical distribution (up to latitudes of $35-40^{\circ}$ ) indicates that cultivars differ markedly in sensitivity. Flower initiation and flowering are hardly affected by day length in popular subtropical cultivars. Most tropical cultivars show quantitative short-day responses, but qualitative responses also occur. The shortest critical day length reported is 12.30 hours. This explains why flowering of local cultivars of common okra is only quantitatively affected by day length in the coastal areas of the Gulf of Guinea $\left(5^{\circ} \mathrm{N}\right)$. However, more inland at higher latitudes $\left(10^{\circ} \mathrm{N}\right)$ one can occasionally observe very tall non-flowering plants of common okra due to a qualitative response. Okra tolerates poor soils, but prefers well-drained sandy loams, with $\mathrm{pH}$ 6-7, and a high content of organic matter (Lamont 1999, Adilakshmi et al. 2008, Akanbi et al. 2010, Akande et al. 2010). Okra requires a moderate rainfall of $80-100 \mathrm{~cm}$ well distributed to produce its young edible fruits over a relatively long period. An average temperature of $20^{\circ} \mathrm{C}$ to $30^{\circ} \mathrm{C}$ is considered optimum for growing, flowering and fruiting (Akinyele \& Temikotan 2007, Dada \& Fayinminnu 2010).

\section{Propagation and Planting}

Most farmers harvest seed from their own local cultivar or rather heterogeneous landrace (Moekchantuk \& Kumar 2004). The easiest way to keep the seed is to leave it in the pods. Seed

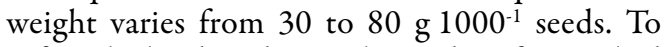
soften the hard seed coat, the seed is often soaked in water or chemicals prior to sowing. The seed is usually dibbled directly in the field (2-3 seeds per hole). Optimum plant densities are in the range of 50,000 - 60,000 plants ha ${ }^{-1}$ (Olasotan 2001). Emergence is within one week. When the plants are about $10 \mathrm{~cm}$ tall, they are thinned to one plant per hole. Germination and initial growth are improved greatly by cultural practices that lower soil temperature, e.g. mulching, watering before the hottest part of the day, and sowing on ridge sides least exposed to direct sunlight (Splittstoesser 1984, Doijode 2001).

\section{Integrated Management}

Commercial okra growers usually practice sole cropping, and prefer the early, homogeneous, introduced cultivars. In traditional agriculture, farmers grow their okra landraces in home gardens or in fields with other food crops (Rashid et al. 2002). In West and Central Africa the landraces often consist of a mixture of Abelmoschusesculentus and Abelmoschus caillei, the former being predominant in dry climates, the latter in humid climates (Dabire-Binso et al. 2009). The uptake of minerals is rather high. Indicative figures for total nutrient uptake per hectares of a crop with a fruit yield of about $10 \mathrm{t} \mathrm{ha}^{-1}$ are $100 \mathrm{~kg} \mathrm{~N}, 10$ $\mathrm{kg}$ P, $60 \mathrm{~kg} \mathrm{~K}, 80 \mathrm{~kg} \mathrm{Ca}$ and $40 \mathrm{~kg} \mathrm{Mg}$ (Kumar et al. 2010). Under humid tropical conditions a full grown crop consumes about $8 \mathrm{~mm}$ of water per day. A ration crop flowers soon after cutting, but usually results in poor quality fruit with a high percentage of bent fruits (Purseglove 1987, Anant \& Manohar 2001). 


\section{Irrigation and Watering Systems}

Thailand has an abundance of water, but growing demand, regional deficiencies and problems with contamination have placed pressure on the resource. Large-scale deforestation also has increased watershed degradation (DoAE 2002). 5.76 million ha are irrigated (mostly for rice), with $46 \%$ in central, $26 \%$ in the northern, $17 \%$ in the northeast and $12 \%$ in the southern regions with increasing pressures on supply, cost-effective strategies are needed to ensure sustainability. Improved technologies are available but costs (and also access in some areas) are a constraint. Strategic use of on-farm storage can lift productivity in dry areas (DoAE 2007, Tipraqsa et al. 2007).

\section{Plant Protection Issues in Export Okra Production}

In general, misuse and over-use of pesticides were not a major issue for the export okra cultivation in Thailand, but export data clearly indicate a major dip in export during 2000, when several consignments of the fresh okra from Thailand were rejected from the Japanese market because of high levels of pesticide residues (Moekchantuk \& Kumar 2004). A collaborative effort by okra export companies and the Department of Agricultural Extension created considerable awareness among farmers and also introduced methods under the "Safe Vegetables" campaign to reduce the use of pesticides. Under this same campaign, home-made pesticide brews were promoted to further replace the dependency of the okra farmers on chemical pesticides. However, following visits to the okra fields and discussions with several farmers, it was found that the brews were largely ineffective in reducing pest populations. Currently, chemical insecticides along with Bacillus thuringiensis (BT) and locallyfermented herbal pesticides are extensively used by farmers to manage pest problems (Rashid et al. 2002). The export companies select the type and doses of agro-chemical inputs, generally to an extent necessary to keep residues below the Maximum Residue Levels (MRLs) set by the major importing companies (Odeleye et al. 2005).

\section{Insect Pests and Diseases in Okra Production}

Okra is susceptible to a large range of insect pests and diseases (N'Guessan et al. 1992, Ghanem 2003). Various growth stages of the crops are susceptible to the different insect pests and diseases (Ek-amnuay 2007, Fasunwon \& Banjo 2010). Insect pests like crickets can be a problem during germination/seedling stage of the crop while the thrips, whitefly and other phloem feeders are common during vegetative stage (Fajinmi \& Fajinmi 2010) (Tab. 3). The incidence pattern of insect pests and diseases are more or less common to all growing areas. Yellow Vein Mosaic (YVM) is the most pressing plant protection problem universally faced by all okra growers

Table 3. List of commonly occurring insect pests on okra

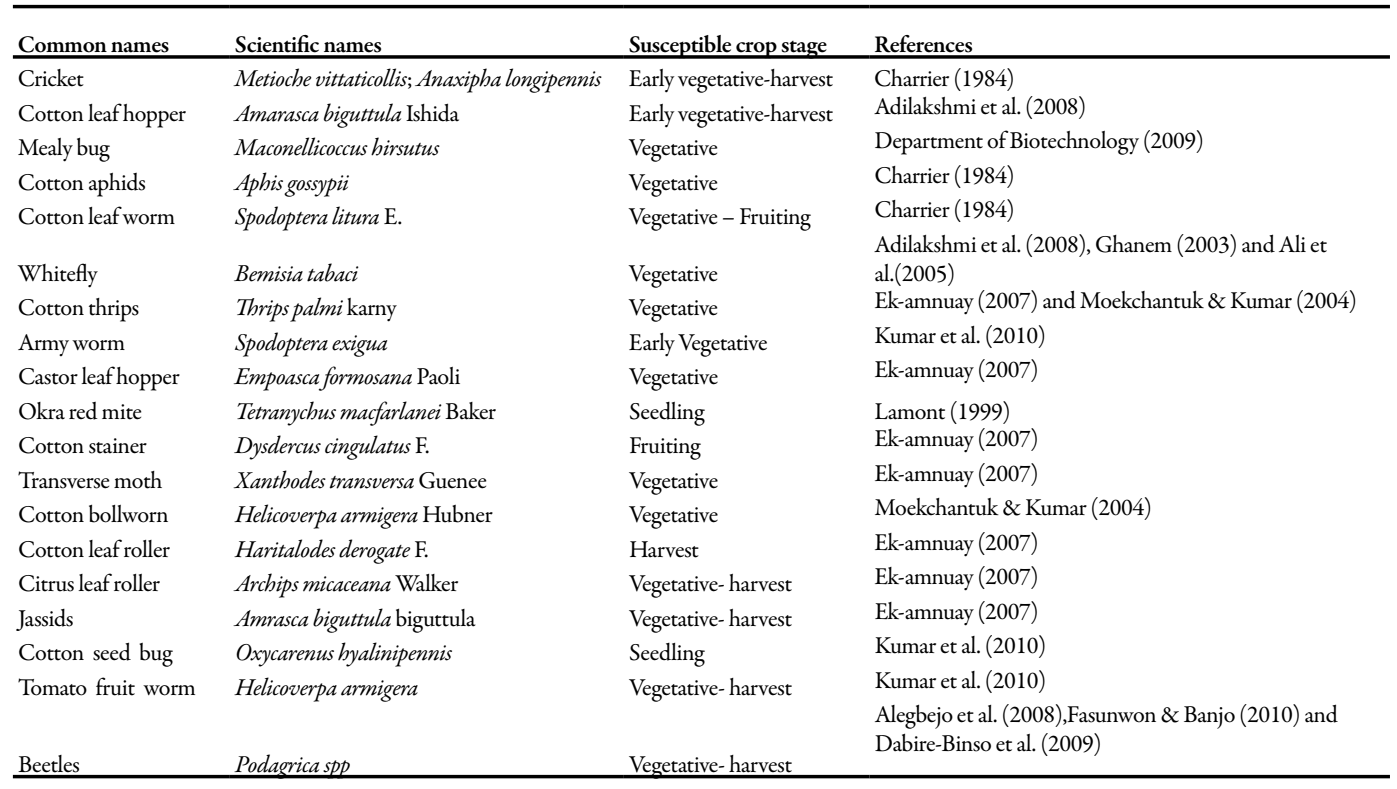


Table 4. List of commonly occurring diseases on okra

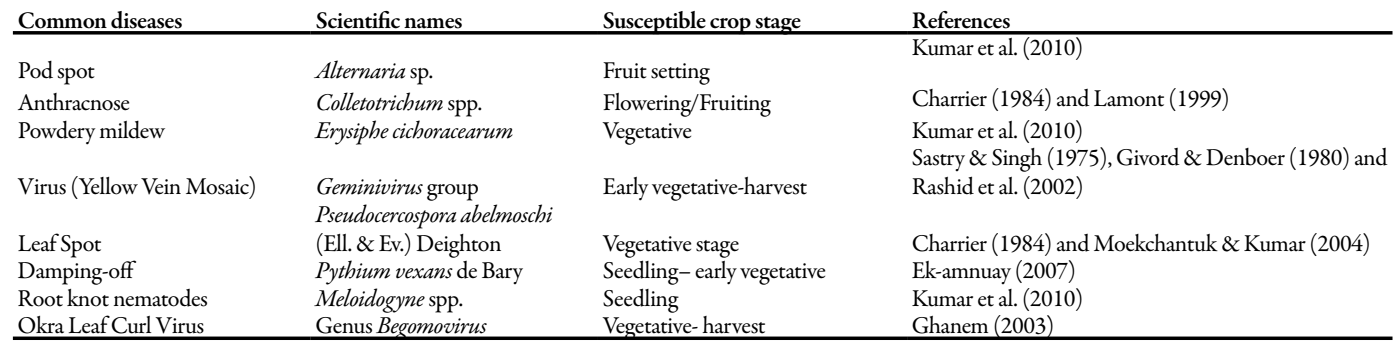

Table 5. Pesticides used against okra insect pests

\begin{tabular}{lll}
\hline \multicolumn{1}{c}{ Trade names } & Active Ingredient & Insect against \\
\hline Dinitrofuran & Carbofuran & Cotton leaf hopper \\
Parathion-methyl & Organophosphates & Cotton leaf hopper \\
Parathion-methyl & Permethrin & Cotton leaf hopper \\
Parathion-methyl & Abamectin & Thrips/whiteflies \\
Home-made herbal & Fermented herbal (home-made) & All insect-pests \\
Proclaim (Syngenta) & Bt (Bacillus thuringiensis) & All defoliator \\
Proclaim (Syngenta) & Emamectin benzoate) & Thrips/whiteflies \\
Paraquat & Paraquat-dichloride & Weeds \\
\hline
\end{tabular}

Source: Moekchantuk \& Kumar (2004)

(Ndunguru \& Rajabu 2004, Alegbejo et al. 2008, Benchasri 2012) (Tab. 4). This jassid transmitted virus disease seriously stunts plant growth, reduces available leaf area for photosynthesis resulting into serious yield and quality loss (Sastry \& Singh 1974, Ali et al. 2005). The vein and veinlets of affected plants turn yellow and even the fruit produced by such plants turn yellow in colour (Rashid et al. 2002). The viruleferous population of vectors has potential to turn a large tract of healthy okra crop into an unproductive one in a short span of time. Virus resistant and tolerant commercial varieties ( $F_{1}$ hybrid and Open Pollination) are available for management of this disease in countries like India and Japan (Weerasekar 2006). Moreover, chemicals and insecticides were also used to control in many countries (Dabire-Binso et al. 2009) (Tab. 5).

\section{Harvesting}

Normally, okra pods are harvested every second day from the time the first pod is formed. It takes 5 to 10 days from flowering to picking fruits ready for the markets (Adetuyi et al. 2008). Harvesting is usually done early in the morning, after which it enters the market (Moekchantuk \& Kumar 2004). Thailand market prefers small, tender fruits on every alternate day of okra. It is important to harvest this plant frequently to increase the yield and to spur the growth (Varmudy 2011). Fresh okra can be transported quite easily in bulk and kept for a few days without much loss of quality (Lamont 1999).

\section{Breeding Goals}

In some parts of the world, breeding of common okra has only been carried out to a limited scale by the commercial sector. A seed company in Senegal distributes improved African cultivars, suitable for the hot and cool season, and the $F_{1}$ hybrid with high tolerance to virus diseases and suitable for export. African farmers have selected an enormous diversity of forms which fit within a great variety of cropping systems. Some of these are available from local seed houses. International breeding efforts have been oriented towards intensive cultivation with high production in a short period (early maturity) and wide adaptation (photoperiod insensitivity, resistance to insects and diseases). Crossing between promising parents combined with pedigree selection or backcrossing remains the most common breeding procedure. Several attractive American and Indian cultivars have found their way to commercial growers throughout the tropics and subtropics, but there is still plenty of scope for cultivar improvement in Africa for the commercial sector (where good 
alternatives for the introduced cultivars are needed with better adaptation to local conditions) as well as for the traditional sector (where hardy, robust, longlived types are required). Nevertheless, molecular markers analyses have shown a rather low level of genetic diversity in cultivated okra in spite of large phenotypic variability. There is little information on improvement using biotechnology apart from in vitro DNA extraction and plant regeneration from various explants and callus tissue. The characteristics of okra species open up new opportunities for recombination. They cross readily in both directions and crosses result in vigorous hybrids for sustainable okra product in the future.

\section{Reference}

Abd El-Kader AA, Shaaban SM, Abd El-Fattah MS (2010): Effect of irrigation levels and organic compost on okra plants (Abelmoschus esculentus $\mathrm{L}$ ) grown in sandy calcareous soil. Agric. Biol. J. North America 1: 225-231

Adetuyi FO, Osagie AU, Adekunle AT (2008): Effect of Postharvest Storage Techniques on the Nutritional Properties of Benin Indigenous Okra Abelmoschus esculentus (L) Moench. Pakistan J. Nutrit. 7: 652-657

Adilakshmi A, Korat DM, Vaishnav PR (2008): Effect of organic manures and inorganic fertilizers on insect pests infesting okra. Karnataka J. Agric. Sci. 21: 287-289

Akanbi WB, Togun AO, Adeliran JA, Ilupeju EAO (2010): Growth dry matter and fruit yields components of okra under organic and Inorganic sources of nutrients. American-Eurasian J. Sustain. Agric. 4: 1-13

Akande MO, Oluwatoyinbo FI, Adediran JA, Buari KW, Yusuf IO (2003): Soil amendments affect the release of P from rock phosphate and the development and yield of okra. J. Veg. Crop Product. 9: 3-9

Akande MO, Oluwatoyinbo FI, Makinde EA, Adepoju AS, Adepoju IS (2010): Response of okra to organic and inorganic fertilization. Nature Sci. 8: 261-266

Akintoye HA, Adebayo AG, Aina OO (2011): Growth and yield response of okra intercropped with live mulches. Asian J. Agric. Res. 5: 146-153

Akinyele BO, Temikotan T (2007): Effect of variation in soil texture on the vegetative and pod characteristics of okra (Abelmoschus esculentus (L.) Moench). Intern. J. Agric. Res. 2: 165-169

Aladele SE, Ariyo OJ, Lapena R (2008): Genetic relationship among West African okra (Abelmoschus caillei) and Asian genotypes (Abelmoschus esculentus) using RAPD. African J. Biotechnol. 7: 1426-1431

Alegbejo M, Ogunlana M, Banwo O (2008): Survey for incidence of okra mosaic virus in northern Nigeria and evidence for its transmission by beetles. Spanish J. Agric. Res. 6: 408-411

Ali S, Khan MA, Rasheed A.H.S, Iftikhar Y (2005): Management of yellow vein mosaic disease of okra through pesticide/bio-pesticide and suitable cultivars. Intern. J. Agric.Biology 7: 145-147

Anant B, Manohar RK (2001): Response of okra to biofertilizers. Indian Society of Vegetable Science 28: 197-198

Arapitsas P (2008): Identification and quantification of polyphenolic compounds from okra seeds and skins. Food Chem. 110: 1041-1045

Benchasri S (2012): Screening for yellow vein mosaic virus resistance and yield loss of okra under field conditions in Southern Thailand. J. Animal Plant Sci. 12: 1676-1686

Benjawan C, Chutichudet P, Kaewsit S (2007): Effect of green manures on growth yield and quality of green okra (Abelmos- chus esculentus L) har lium cultivar. Pakistan J. Biological Sci. 10: 1028-1035

Burkil HM (1997): The useful plant of west tropical Africa, Royal Botanic Gardens, Kew, UK

Charrier A (1984): Genetic resources of Abelmoschus (okra). IBPGR Secretarial, Paris, France

Chauhan DVS (1972): Vegetable production in India, Ram Prasad and Sons, India

Chevalier A (1940): Origine la culture et les usages de cinq $\mathrm{Hi}$ biscus de la section Abelmoschus. Rev. Bot. App. Agric. Trop. 20: 319-328

Chizaki Y (1934): Breeding of a new interspecific hybrid between Hibiscus esculentus L. and H. manihot L.). Proc. Crop Sci. Soc. (Japan) 6: 164-172

Dabire-Binso CL, Ba MN, Some K, Sanon A (2009): Preliminary studies on incidence of insect pest on okra, Abelmoschus esculentus (L.) Moench in central Burkina Faso. African J. Agric. Res. 4: 1488-1492

Dada OA, Fayinminnu OO (2010): Period of weed control in okra [Abelmoschus esculentus (L.) Moench] as influenced by varying rates of cattle dung and weeding regimes. Notulae Botanicae Horti Agrobotanici Cluj-Napoca 38: 149-154

Datta PC, Naug A (1968): A few strains of Abelmoschus esculentus (L.) Moench their karyological in relation to phylogeny and organ development. Beitr. Biol. Pflanzen. 45: 113-126

Department of Biotechnology (2009): Series of crop specific biology documents biology of okra. Ministry of Science and Technology Government of India

Dilruba S, Hasanuzzaman M, Karim R, Nahar K (2009): Yield response of okra to different sowing time and application of growth hormones. J. Hortic. Sci. Ornamental Plants 1: 10-14

DoAE (2002): Vegetable group; Department of Agriculture Extension, Royal Thai Government. Bangkok, Thailand

DoAE (2007): Thailand DoAE- FAO vegetable IPM Regional training on biological control. FAO-inter country programme for IPM in vegetable in South and Southeast Asia

Doijode SD (2001): Seed storage of horticultural crop. Food Product Press, New York, USA

Ek-Amnuay P (2010): Plant diseases and insect pests of economic crops. Amarin Printing and Publishing Public Co. Ltd, Bangkok, Thailand. $379 \mathrm{pp}$.

Fajinmi AA, Fajinmi OB (2010): Incidence of okra mosaic virus at different growth stages of okra plants (Abelmoschus esculentus (L.) Moench) under tropical condition. J. General Molec. Virology 2: 28-31

Fasunwon BT, Banjo AD (2010): Seasonal population fluctuations of Podagrica Species on okra plant (Abelmoschus esculentus). Res. J. Agric. Biolog. Sci. 6: 283-288

Ford CE (1938): A contribution to a cytogenetical survey of the Malvaceae. Genetica 20: 431-452

Gadwal VR, Joshi AB, Iyer RD (1968): Interspecific hybrids in Abelmoschus through ovule and embryo culture. Indian J. Genet. Plant Breed 28: 269-274

Ghanem GAM (2003): Okra leaf curl virus: a monopartite begomovirus infecting okra crop in Saudi Arabia. Arab J. Biotechnol. 6: 139-152

Givord L, Denboer L (1980): Insect transmission of okra mosaic virus in the Ivory Coast. Annals Appl. Biol. 94: 235-241

Gopalan C, Sastri SBV, Balasubramanian S (2007): Nutritive value of Indian foods, National Institute of Nutrition (NIN), ICMR, India

IBPGR (1991): Report of international workshop on okra genetic resources. National Bureau for Plant genetic Resources (NBPGR), New Delhi, India

Joshi AB, Hardas MW (1953): Chromosome number in Abelmoschus tuberculatus $\mathrm{Pal} \&$ Singh a species related to cultivated bhindi. Curr. Sci. 22: 384-385

Joshi AB, Hardas MW (1976): Okra. In: Evolution of crop plants. Longmans, London, UK 
Kahlon TS, Chapman MH, Smith GE (2007): In vitro binding of bile acids by okra beets asparagus eggplant turnips green beans carrots and cauliflower. Food Chem. 103: 676-680

Kamalova GV (1977): Cytological studies of some species of the Malvaceae. Biologija Zurnali. 3: 66-69

Kumar R, Patil MB, Patil SR, Paschapur MS (2009): Evaluation of Abelmoschus esculentus mucilage as suspending agent in paracetamol suspension. Intern. J. PharmTech Res. 1: 658-665

Kumar S, Dagnoko S, Haougui A, Ratnadass A, Pasternak D, Kouame C (2010): Okra (Abelmoschus spp.) in West and Central Africa: potential and progress on its improvement. African J. Agric. Res. 5: 3590-3598

Kuwada H (1964): Studies on the varietal characters and its classification of okra. Kagawa Agric Coll. Techn. Bull. 15: 79-88

Kuwada H (1966): The new amphidiploid plant named "Abelmoschus tubercular-esculentus obtained from the progeny of the reciprocal crossing between $A$. tuberculatus and $A$. esculentus. Japan J. Breeding 16: 21-30

Kuwada H (1974): $\mathrm{F}_{1}$ hybrids of Abelmoschus tuberculatus x $A$. manihot with reference to the genome relationship. Japan J. Breed 24: 207-210

Lamont W (1999): Okra a versatile vegetable crop. Hort. Technol. 9: 179-184

Lengsfeld C, Titgemeyer F, Faller G, Hensel A (2004): Glycosylated compounds from okra inhibit adhesion of Helicobacter pylori to human gastric mucosa. J. Agric. Food Chem. 52: 1495-1503

Liu IM, Liou SS, Lan, TW, Hsu FL, Cheng JT (2005): Myricetin as the active principle of Abelmoschus moschatus to lower plasma glucosein streptozotocin-induced diabetic rats. Planta Medica 71: 617-621

Markose BL, Peter KV (1990): Okra review of research on vegetable and tuber crops. Kerala Agricultural University Press, Kerala, India

Moekchantuk T, Kumar P (2004): Export okra production in Thailand. Inter-country programme for vegetable IPM in South \& SE Asia phase II Food \& Agriculture Organization of the United Nations, Bangkok, Thailand

Ndunguru J, Rajabu AC (2004): Effect of okra mosaic virus disease on the above-ground morphological yield components of okra in Tanzania. Scientia Horticulturae 99: 225-235

N'Guessan KP, Fargette D, Fauquet C, Thouvenel JC (1992): Aspects of the epidemiology of okra leaf curl virus in Côte d'Ivoire. Tropical Pest Manag. 38: 122-126

Odeleye FO, Odeleye OMO, Dada OA, Olaleye AO (2005): The response of okra to varying levels of poultry manure and plant population density under sole cropping. J. Food Agric. Environ. 3: 68-74

Olasotan FO (2001): Optimum population density for okra (Abelmoschus esculentus (L) Moench) in a mixture with cassava (Manihot esculentus) and its relevance to rainy season-based cropping system in south-western Nigeria. J. Agric. Sci. 136 207-214
Owolarafe OK, Shotonde HO (2004): Some physical properties of fresh okra fruit. J. Food Engin. 63: 299-302

Purewal SS, Randhawa GS (1947): Studies in Hibiscus esculentus (Lady's finger). 1. Chromosome and pollination studies. Indian J. Agric. Sci. 17: 129-136

Purseglove JW (1987): Tropical crop dicotyedons. Language Book Sosiety Longman, London, UK

Qhureshi Z (2007): Breeding investigation in bhendi (Abelmoschus esculentus (L.) Moench). Master Thesis, University of Agriculture Sciences, GKVK, Bangalore

Rashid MH, Yasmin L, Kibria MG, Mollik AKMSR, Hossain SMM (2002): Screening of okra germplasm for resistance to yellow vein mosaic virus under field conditions. Pakistan J. Plant Pathol. 1: 61-62

Rubatzky VE, Yamaguchi M (1997): World vegetables: principles, production, and nutritive values. Chapman and Hall, New York, USA

Saifullah M, Rabbani MG (2009): Evaluation and characterization of okra (Abelmoschus esculentus L. Moench.) genotypes. SAARC J. Agric. 7: 92-99

Sastry KSM, Singh SJ (1974): Effect of yellow-vein mosaic virus infection on growth and yield of okra crop. Indian Phytopathol. 27: 294-297

Savello PH, Martin FW, Hill JM (1980): Nutritional composition of okra seed meal. J. Agric. Food Chem. 28: 1163-1166

Siemonsmo JS (1982): West African okra morphological and cytological indications for the existence of a natural amphiploid of Abelmoschus esculentus (L) Moench and A. Manihot (L) Medikus. Euphytica 31: 241-252

Siemonsma JS, Kouame C (2000): Abelmoschus esculentus (L.) Moench. Wageningen Agricultural University, Wageningen, Netherlands

Singh HB, Bhatnagar A (1975): Chromosome number in an okra from Ghana. Indian J. Genet. Plant Breed. 36: 26-27

Splittstoesser WE (1984): Vegetable growing handbook. The AVI Publishing Co. Westport, New Zealand

Tindall HD (1983): Vegetables in the tropics. Macmillan Education Limited, London, UK

Tipraqsa P, Craswell ET, Noble AD, Schmidt-Vogt D (2007): Resource integration for multiple benefits: multifunctionality of integrated farming systems in Northeast Thailand. Agric. Sys. 94: 694-703

Tischler G (1931): Pflanzliche chromosomen-zahlen (Nachtrag no. 1) Tabulae Biol. 7: 109-226

Ugale SD, Patil RC, Khuspe SE (1976): Cytogenetic studies in the cross between Abelmoschus esculentus and A. tetraphyllus. J. Maharashtra Agric. Univer. 1: 106-110

Varmudy V (2011): Marking survey need to boost okra exports. Department of economics, Vivekananda College, Puttur, Karnataka, India

Weerasekar D (2006): Genetical analysis of yield and quality parameters in okra (Abelmoschus esculentus (L) Moench). Master thesis, University of Agricultural Sciences. GKVK, Bangalore

\section{Bamija (Abelmoschus esculentus (L.) Moench) kao važna povrtarska vrsta u svetu}

\section{Sorapong Benchasri}

Izvod: Bamija je komercijalna povrtarska vrsta koja se gaji na značajnim površinama u Africi i Aziji. Pripada porodici Malvaceae i verovatno vodi poreklo iz Etiopije. Ima važnu ulogu u ljudskoj ishrani kao izvor masti, belančevina, ugljenih hidrata, mineral i vitamina. U radu je dat pregled hemijskog sastava, porekla, proizvodnje i rasprostranjenosti, agrotehničkih mera, zaštite bilja i ciljeva u oplemenjivanju bamije sa posebnim osvrtom na tržište Tajlanda.

Ključne reči: Abelmoschus esculentus, agrotehničke mere, bamija, bolesti, oplemenjivanje, poreklo, proizvodnja, sastav, štetočine 